\title{
Teaching the Information Society: A One-day Symposium, hosted by the School of Communication Arts, Napier University, Edinburgh, 18th May 2001
}

Welcome to this special 'conference edition' of Education for Information - or to be more accurate, 'symposium edition'. I will try to defend the pedantry later. But first the subject matter needs to be justified and the several contributions introduced.

The work presented below is entirely predicated on an unambiguous and ambitious claim, namely that there exists, at least in nascent form, a research specialism - if not a field - devoted to the study of information in society. This specialism (as I will call it here) goes by various names, including straightforwardly 'information in society' and, rather more tendentiously, 'information society studies'. It is interested in that mighty, epoch-defining concept, information, and its complex and perhaps partially deterministic relationship with the large-scale communities we call societies. Much more detailed characterisations are offered below in the papers by Alistair Black and myself, but enough has already been said to show that the specialism in question extends very much beyond the conventional borders of librarianship and information science. It is about (among others) sociology, economics, political philosophy, social policy, the disciplines which help us both to understand the social world and to articulate the rules which should govern the social world - or in the words of the philosopher of the Scottish Enlightenment, David Hume, both the 'is' and the 'ought'. But the angle is strictly information in society, the roles information plays and ought in a fairer world to play, an angle that has been somehow neglected by the major disciplines. And therein lies the interest, and hopefully also the special intellectual contribution, of the information scientist and the information professional. For as information seekers, information collectors, information defenders, information purveyors, even the humblest of librarians are - and always have been (note Black's stress below on what he calls 'information history') - at the forefront of the 'informationisation' of society. We may not like the term 'informationisation' or its arguably even uglier alternatives such as 'informatisation' or 'informisation', but we can hardly deny that we are all professionally involved with the positioning of information in society. 'Information society studies' (as I prefer to call it) is, from this point of view, simply the theorisation of the socio-political role of the information professional. Thus even those librarians who are such poor citizens as to be otherwise totally unconcerned with the great issues of politics and society are obliged to enter what Black calls 'the information society debate'.

The next question becomes: how then should we teach this subject? And the short answer is: try every method in the world. For the brutal truth is that information 
society studies is one of the hardest subjects in the information science curriculum to teach. There are several reasons for this. It is, as already mentioned, in a formative stage and therefore lacks the comforting absolutes of a body of established wisdom. I have often found that by week four of a lecture series students are screaming at me, 'Tell us whether you do, or do not, believe we are living in an information society!'. They want certainty and dogma, but all we presently can give them is nuance and ambiguity. Secondly, information society studies is, as also touched on above, multidisciplinary. That too is a recipe for complexity and perplexity, at least for the less able learners who make up an increasing proportion of the university student population. Then there is the perennial vocational/academic issue. Few of us have the privilege of teaching in research universities and we are rarely free from pressure to make our courses explicitly relevant to the work-place. We have to try to strike a balance between engaging in high-level academic enquiry and bringing information society studies down to the level of case studies and the like. This is not easy, especially with mixed-ability classes, but a good teacher can do it. (Incidentally, I should like to point out that it is not only slower learners who tend to favour vocational slants: I have found that teaching information society studies to highly-qualified journalism students, for example, can be no less of an uphill struggle.) And, of course, the more daunting the challenge, the greater the potential reward. There is surely little in this world that can surpass the satisfaction of succeeding in enthusing a class for a difficult subject area, of making a seminar 'sparkle', of seeing on an end-of-module student questionnaire, 'I have come away with an interest in the information society debate'! Alistair Black introduces some of these dimensions, and they are explored further in Susan Hornby's personal and honest (a key pedagogic virtue) account of teaching the information society at a major civic university in England.

Moreover, we who teach the information society hold it to be a self-evident truth that discussion and debate must be at the core of information society studies. That is why we encourage divergent interpretations of the information society in our classes. It is also part of the reason why specialists from all over Britain and Ireland made the effort to gather in Edinburgh for the unique symposium from which the articles in this journal issue are derived. We wanted to learn about how others conceived 'our' subject, how they defended its inclusion in the curriculum, how they taught it, how they assessed it, and how all of these things could be done better. The emphasis was not so much on the presentations themselves as on discussion by delegates of the important questions raised in the course of the presentations. This is what made the gathering more of a symposium, a vital scholarly conversation, than a formal conference. Julian Warner's epilogue comprises a laudable attempt to convey the essence of the discussions that occurred. No doubt it is not a perfect recollection, but it gives at least a glimpse of the varied terrain that was covered. And I hope readers will judge that the day's proceedings lived up to the standards imputed by the social theorist Theodore Roszak in his generous tribute in The Cult of Information: 'Precisely because the library is the public institution under the greatest competitive 
pressure from the new technology, one finds the most urgent questions of information technology and access being addressed more intensely and imaginatively at library conferences and in library journals than anywhere else.' [1].

The final piece in this issue is a specially commissioned opinion from an educationalist who acted as an expert observer at the symposium. Shirley Earl's comments constitute a salutary 'reality check' administered by a colleague on the outside of the charmed circle of information society specialists. Noting the tension between liberal and vocational values in education, she argues for a greater appreciation of the latter, and for an acceptance of the bureaucratic regimes integral to quality review and research assessment. Earl also argues for a shift from a subject focus to a learner focus, or in other words that we need to make students' needs and expectations paramount in the educational process. While neither of these messages will receive universal acceptance among scholars, nothing but good can come from giving them our respectful - and reflective - attention.

\author{
Alistair S. Duff \\ School of Communication Arts \\ Napier University \\ Craighouse Road \\ Edinburgh \\ EH10 5LG \\ UK \\ E-mail: a.duff@napier.ac.uk
}

\title{
Reference
}

[1] T. Roszak, The Cult of Information: a Neo-Luddite Treatise on High-tech, Artificial Intelligence, and the True Art of Thinking, 2 ed., University of California Press, Berkeley, CA, 1994. 